\title{
DETERMINING SPATIO-TEMPORAL CADASTRAL DATA REQUIREMENT FOR INFRASTRUCTURE OF LADM FOR TURKEY
}

\author{
M. Alkan ${ }^{a}{ }^{*}$, Z. A. Polat ${ }^{\text {a }}$ \\ a Department of Geomatics, Faculty of Civil Engineering, Yildiz Technical University, (alkan, zapolat@yildiz.edu.tr)
}

Commission II, WG II/1

KEY WORDS: Land title and cadastral data; Spatio-Temporal requirement, TGIS, LADM

\begin{abstract}
:
Nowadays, the nature of land title and cadastral (LTC) data in the Turkey is dynamic from a temporal perspective which depends on the LTC operations. Functional requirements with respect to the characteristics are investigated based upon interviews of professionals in public and private sectors. These are; Legal authorities, Land Registry and Cadastre offices, Highway departments, Foundations, Ministries of Budget, Transportation, Justice, Public Works and Settlement, Environment and Forestry, Agriculture and Rural Affairs, Culture and Internal Affairs, State Institute of Statistics (SIS), execution offices, tax offices, real estate offices, private sector, local governments and banks. On the other hand, spatio-temporal LTC data very important component for creating infrastructure of Land Administration Model (LADM). For this reason, spatio-temporal LTC data needs for LADM not only updated but also temporal. The investigations ended up with determine temporal analyses of LTC data, traditional LTC system and tracing temporal analyses in traditional LTC system. In the traditional system, the temporal analyses needed by all these users could not be performed in a rapid and reliable way. The reason for this is that the traditional LTC system is a manual archiving system. The aims and general contents of this paper: (1) define traditional LTC system of Turkey; (2) determining the need for spatio-temporal LTC data and analyses for core domain model for LADM. As a results of temporal and spatio-temporal analysis LTC data needs, new system design is important for the Turkish LADM model. Designing and realizing an efficient and functional Temporal Geographic Information Systems (TGIS) is inevitable for the Turkish LADM core infrastructure. Finally this paper outcome is creating infrastructure for design and develop LADM for Turkey.
\end{abstract}

\section{INTRODUCTION}

Cadastral data is the important part of managing land resources. When viewed from this aspect, land registration and cadastral system together play an important role in a society (Liang 2008). Increasing complexity and flexibility of modern land use requires and different demands effect always land registration data and so land registration data is dynamic (Leksono et al. 2011). Changing related to real property (e.g. land parcels) effects changing in land registration data where it could be categorized into two types: spatial changing (physical data) and attribute changing (juridical data) of a land parcel (Zevenbergen 2002; Liang 2008; Zhang \& Tuladhar, 2006; Leksono et al. 2011). Zevenbergen (2002) explains three main things of land registration with regard to the dynamic of land registration system: (1) first land registration, (2) transfer of land rights (the whole land parcels) and (3) parcel mutation/splitting due to partial transfer of land rights. As stated by Leksono et al. (2011), the current land information system is not sufficient no longer to manage spatial changing of land parcels however it only can show the last spatial information. Consequently, there is a need of land information system (Abdulai \& Ansah, 2014) that is proficient to store, manage and represent information of land registration including its changing either spatially or textually.

In Turkey, either land title (LT) or cadastral data changes at the end of some transactions. LT and cadastral data has a great variety of users; legal authorities, various state organizations, private sector companies, local governments, owners and many others need this data (Comert \& Alkan 2004; Alkan and Comert, 2010). This need is not only for updated but also for "temporal data" which mean the data regarding the past or history of real property. Conventional land registry and cadastral system enables temporal analyses. Nevertheless, in most of the cases performing an analysis may be a tedious, time consuming, and error-prone task (Comert \& Alkan 2004; Alkan 2005). Therefore, needed is a Temporal Geographic Information Sytems (TGIS) for LT and cadastral data. As stated by Doner \& Biyik (2013), Inan \& Yomralioglu (2011), Ozcelik \& Nisanci (2015), LADM (Land Administration Domain Model) could be used to model land registration process in Turkey by involving party, RRR (Rights, Responsibilities, and Restrictions), land parcel, and also its spatial representation. By adding dimension of time, its start date and end date, for every line of data which requires investigation of its history, the line of data for a certain time could be acquired (van Oosterom \& Lemmen 2001).

\section{LAND REGISTRY AND CADASTRE SYSTEM IN TURKEY}

Existing cadastre system in Turkey includes cadastral mapping with land registry (Doner \& Biyik 2007; Doner \& Biyik 2013) and the main unit is a 2-Dimensioned parcel (Aydin 2008). While land registry and cadastral work is done under the control of General Directorate of Land Registry and Cadastre (GDLRC) 
(Alkan 2005; Aydin 2008; Doner \& Biyik 2007), rights of property are under state guarantee (Cay et al. 2009). Cadastral works in Turkey were started in Ottoman Empire period in 1912 but were left unfinished due to the war and were started again with Law No 658 in 1925 after the foundation of Turkish Republic (Doner \& Biyik 2007; Aydin 2008; Ayazli et al. 2008; Cay et al. 2009). Cadastral works made until 1950 were mostly limited with urban areas (Doner \& Biyik 2007). After World War II, there was a need for determining and registering agricultural areas and cadastral works spread to all urban and rural areas (Alkan 2005; Kucukmehmetoglu \& Geymen 2016). Works in this period were according to Land Registry Law No 5602 (Aydin 2008; Ayazli et al. 2008). This law was reissued as Land Registry Law No 766 after the changes in 1964 and 1966. Cadastral works in rural and urban areas until 1987 were made under these two laws (Doner \& Biyik 2007; Aydin 2008; Ayazli et al. 2008). Today all these cadastral works and regulations are made according to the provisions of Cadastral Law No 3402 coming into force in 1987 (Demir et al. 2003; Alkan 2005; Doner \& Biyik 2007).

In the current land title and cadastre system of Turkey, real estates such as land parcels, buildings, apartments, business offices etc. are defined with two general types of information. These types are named as "land title data" and "cadastral data" in this article. Land title data involves ownership identities such as name, last name, father name of the owner. The date and transaction via which the ownership was gained is also included (Comert and Alkan, 2004). In addition, ownership rights and responsibilities such as mortgages on the estate, rights of third parties on the estate are components of land title data. Cadastral data, on the other hand, determines the location in a coordinate system and the shape of the estate. At the moment, cadastral data is maintained in either analog or digital medium (Comert and Alkan, 2004). In Turkey, both types of data are handled by two separate state organizations; Land Title Offices (LTO) and Cadastre offices (CO).

\section{BRIEF REVIEW OF ISO 19152 LAND ADMINISTRATION DOMAIN MODEL (LADM) AND ITS TEMPORAL ASPECTS}

Traditional land registry and cadastral systems are unsatisfactory in meeting all land requirements. For this reason, need for sustainable land management model occurred in order to manage, present and archive land-related information and documents (Leksono et al. 2011). Even though many scientific searches are made in order to provide standardization in land administration field, they were limited in many aspects (e.g. extensiveness, scope and content) because of the uncommon characteristics of Land Administration Systems (LAS) worldwide (Inan \& Yomralioglu 2011).

In order to provide standardization for the main common characteristics of LASs, spatial data modelling studies were brought up by van Oosterom \& Lemmen (2002) in 2002 for the first time. These studies called Core Cadastral Domain Model in the beginning stage are managed in cooperation with International Federation of Surveyors (FIG) under Land Administration Domain Model (LADM) in the latter stage. Later, the model was given a standard number after being accepted under the name ISO 19152 Land Administration Domain Model (LADM) by ISO in 2012 (Paasch et al. 2015).
LADM has capability to provide an abstract description and conceptual schema (van Oosterom \& Lemmen 2015; Lemmen et al. 2015; Aien et al. 2013b; Aien et al., 2013a) concerning land administration components such as parties (person and organization), basic administrative units and RRR in case of ownership, spatial unit (e.g. parcels, buildings, and networks), spatial source (measurement) and spatial representation (geometry and topology) (Figure 1). LADM also gives terminology (Paasch et al. 2015) for land administration based on either national or international system that is developed as simple as possible for practical purposes (Kalantari et al. 2015; Leksono et al. 2011).

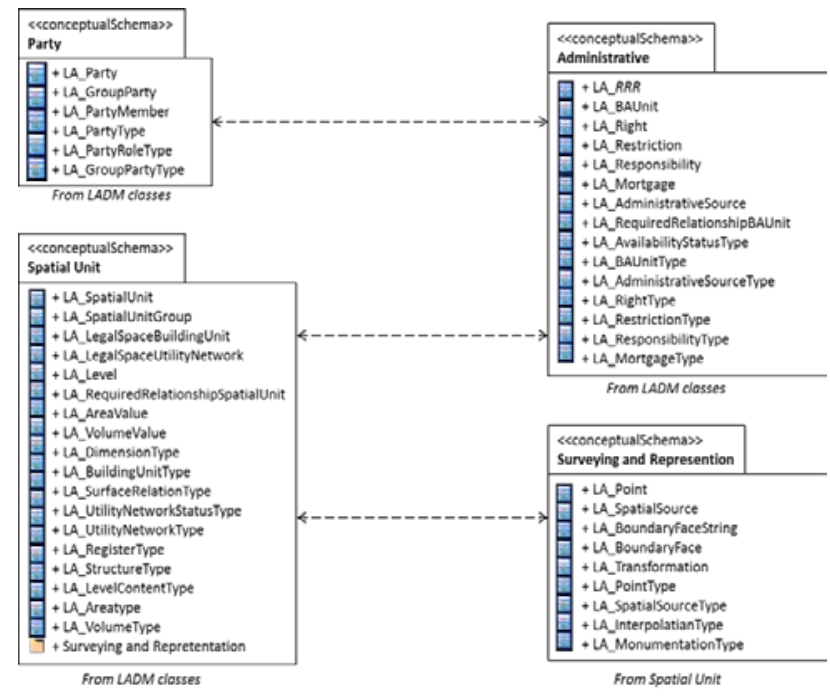

Figure 1: The LADM overview of (sub) packages (with their respective classes) (ISO, 2012).

The LADM has a special class called Object Version to model event based modeling and state based modeling where it. This modeling is performed by defining the validity of time for each class. The temporal data in the database is managed and maintained in LADM by the introduction of the ClassVersionedObject (Figure 2) (Lemmen 2012). This special class plays important role in forming spatial temporal database (Leksono et al. 2011). The inserted and superseded data are given a time stamp. At any historical time, the contents of the database can be represented as they were (Babalola et al. 2015). The generic data type Oid is introduced to provide support for object identifiers in LADM. In principle, the updating, retrieving and management of the database is based on correct source documents, which cannot be changed (Babalola et al. 2015).

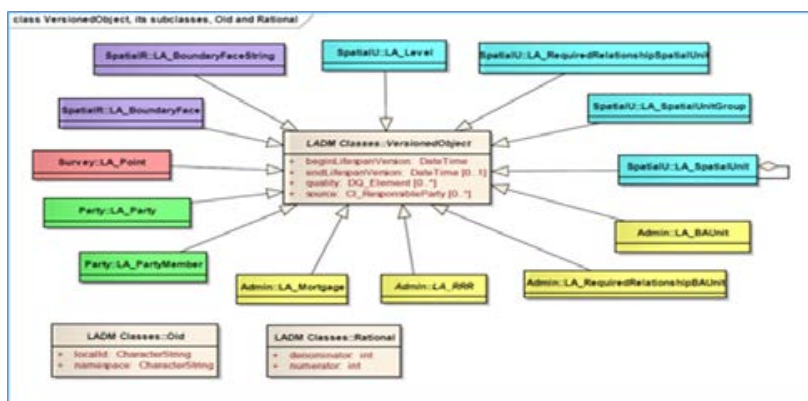

Figure 2: The representation of spatial temporal elements using LADM (Leksono et al. 2011; Babalola et al. 2015). 


\section{MODEL DESIGN BASED ON ISO 19152 LAND ADMINISTRATION DOMAIN MODEL (LADM)}

In this study, conformity of LADM for modeling easement rights in terms of temporal cadastre situations in Turkey was evaluated. For testing the designed model, the easements registered in the land registry were examined. The main types of recorded easements can be listed as follows (the Turkish terms are added in italic, in brackets).

- Right of superficies (üst hakkı)

- Right of usufruct (yararlanma hakkı)

- Right of passage (geçit hakkı)

- Right of water (kaynak hakk1)

- Right of residence (oturma hakk1)

The application schema of temporal cadastral database was prepared applying UML notation, according to the ISO 19100 series standards methodology, as well. The first step was to chose the main classes of Turkish temporal cadastral model, provide them with English names and assign related LADM classes. The prefix "TR_" was added to the class name for application in the country profile instead of original prefix "TK_". The main classes of Turkish temporal cadastral data model applied in the country profile for Turkey are shown in the Table 1 .
Table 1: The main classes of Turkish temporal cadastral data model classes of Turkey's country profile and related ISO 19152 LADM classes.

\begin{tabular}{|c|c|c|c|}
\hline $\begin{array}{l}\text { Turkish model original class } \\
\text { name }\end{array}$ & $\begin{array}{l}\text { Name in the Turkey's } \\
\text { profile }\end{array}$ & $\begin{array}{l}\text { Corresponding } \\
\text { LADM class }\end{array}$ & Corresponding LADM subclass \\
\hline TK__irtifakHaklarl & TR_Easement & LA_Right & $\cdot$ \\
\hline TK__Kistilliklar & TR_Restrictions & TR_Restrictions & $\cdot$ \\
\hline TK_Sorumluklar & TR_Responsibilities & TR_Responsibilities & $\cdot$ \\
\hline TK_ÜstHakkı & TR_RightOfSuperficies & LA_Right & LA_EasementRightType \\
\hline TK__YararlanmaHakkl & TR_RightOfUsuffuct & LA_Right & LA_EasementRightType \\
\hline TK_Geçithakkı & TR_RightOfPassage & LA_Right & LA_EasementRightType \\
\hline TK_KaynakHakkl & TR_RightOfWater & LA_Right & LA_EasementRightType \\
\hline TK_OturmaHakkı & TR_RightOfResidence & LA_Right & LA_EasementRightType \\
\hline TK_ResmiBelgeler & TR_AdministrativeSourceType & LA_Source & TR_AdministrativeSourceType \\
\hline $\begin{array}{l}\text { TK_Hakknil|gilioldugüuTașin } \\
\text { mazTipi }\end{array}$ & $\begin{array}{l}\text { TR_TypeOfRealPropertyRelated } \\
\text { ToRights }\end{array}$ & LA_Right & LA_EasementRightType \\
\hline TK_IIrtifakHakknnıSS̈resi & TR_DurationOfEasement & LA_Right & LA_EasementRightType \\
\hline TK__irtifakHakkınınBedeli & TR_CostOfEasement & LA_Right & LA_EasementRightType \\
\hline
\end{tabular}

In this context, the connections between main classes of easements section of Turkish temporal cadastral data model were identified. The relationships between classes like LA_Party, LA_RRR, LA_BAunit, LA_SpatialUnit, TR_EasementRight, TR_AdminisrativeSource and TR_SpatialSource were presented in Figure 3.

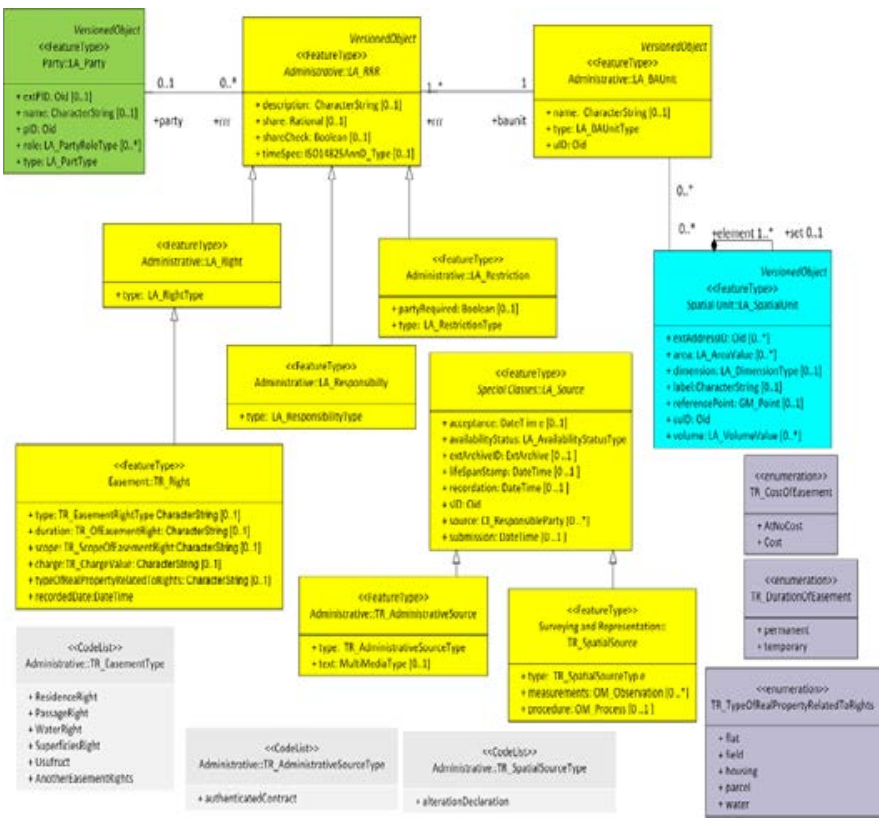

Figure 3: Schema of relationships between classes concerning Parties and Rights (Easements) to Properties of Turkish temporal cadastral data model.

\section{CONCLUSION}

This paper proposes a temporal cadastral data model based on the Land Administration Domain Model (LADM), ISO 19152, 
than described in the current standard the LADM's 'right', 'restriction' and 'responsibility' (RRR) class and associated code lists. Most recorded easement rights in Turkish Land Registry Sistem have been selected for the implementation this model. Due to designed model, it was proven that all easement cases could be represented very well in standard LADM. Finally, a standard temporal cadastral information model establishment plan using ISO 19152 (LADM) has been suggested for efficient connection and integration between systems, information sharing, and smooth provision tovarious fields as cadastral information management.

\section{REFERENCES}

Abdulai, R.T., Ansah, A.O., 2014. Land information management and landed property ownership security: Evidence from state-sponsored court system. Habitat International, 42, 131-137.

Aien, A., Kalantari, M., Rajabifard, A., Williamson, I., Wallace J., 2013a. Towards Integration of 3D Legal and Physical Objects in Cadastral Data Models. Land Use Policy, 35, pp. 140-154.

Aien, A., Kalantari, M., Rajabifard, A., Williamson, I., Bannet, R., 2013b. Utilising data modelling to understand the structure of 3D cadastres, Journal of Spatial Science, 58:2, 215-234

Alkan, M., 2005. Tapu ve Kadastro Verilerine Yönelik Zamansal Coğrafi Bilgi Sistemi Tasarımı. Doctoral Thesis. Karadeniz Technical University, Institute of Natural Sciences. Turkey (In Turkish).

Alkan, M., Comert, C., 2010. A design of temporal geographic information systems (TGIS) for Turkish land register and cadastre data. Scientific Research and Essays, 5(7), pp. 700708 .

Ayazli, E., Batuk, F., \& Stoter, J., 2008. Three Dimensional Property Right Problems and Suggestions for Turkey. The International Archives of the Photogrammetry, Remote Sensing and Spatial Information Sciences, Vol. XXXVII. Part B2. Beijing.

Aydin, C.C., 2008. Usage of Underground Space for 3D Cadastre Purposes and Related Problems in Turkey. Sensors, 8, 6972-6983.

Babalolaa, S.O., Rahman, A.A., Choon, L.T., Van Oosterom, P.J.M., 2015. Possibilities of Land Administration Domain Model (LADM) Implementation in Nigeria. ISPRS Annals of the Photogrammetry, Remote Sensing and Spatial Information Sciences, Volume II-2/W2.

Cay, T., Adibelli, S., Iscan, F., 2009. A proposal for the cadastral system in Turkey. Proceedings of the Institution of Civil Engineers Municipal Engineer, 162, Issue ME4.

Comert, C., Alkan, M., 2004. The Design and Development of a Temporal GIS For Cadastral and Land Title Data of Turkey. International Society of Photogrametry and Remote Sensing, XXth Congress, 12-23 July, İstanbul, Turkey.
Demir, O., Atasoy, M., Aydin, C.C., Biyik, C., 2003. A Case Study for determining the Turkish Cadastre Contents. In Proceedings of 2nd FIG Regional Conference, December 2-5, Marrakech, Morocco.

Doner, F. \& Biyik, C., 2007. Defining 2D Parcels in 3D Space by Using Elevation Data. FIG Working Week 2007, TS 8G Innovative Technology and Solutions in Land Administration.

Doner, F., Thompson, R., Stoter, J., Lemmen, C., Ploeger, H., Van Oosterom, P., Zlatanova, S., 2011. Solutions for 4D cadastre - with a case study on utility networks. International Journal of Geographical Information Science, 25:7, 11731189.

Doner, F., Biyik, C., 2013. Conformity of LADM for Modeling 3D/4D Cadastre Situations in Turkey. 5th Land Administration Domain Model Workshop, 24-25 September 2013, Kuala Lumpur, Malaysia.

GDLRC, 2015. 2014 Annual report. Strategy Development Department of GDLRC. http://www.tkgm.gov.tr .

Inan, H.I., Yomralioglu, T., 2011. Arazi İdaresi İçin Konumsal Modelleme. HKMO Jeodezi, Jeoinformasyon ve Arazi Yönetimi Dergisi, 2011/1 Say1 104. (In Turkish).

ISO, 2012. ISO/FDIS 19152:2012 Geographic information Land Administration Domain Model (LADM).

Kalantari, M., Rajabifard, A., Wallace, J., Williamson, I.P., 2008. Spatially Referenced Legal Property Objects. Journal of Land Use Policy, Vol. 25, Issue 23, p173-181.

Kalantari, M., Dinsmore, K., Urban-Karr, J., Rajabifard, A., 2015. A roadmap to adopt the Land Administration Domain Model in cadastral information systems. Land Use Policy, 49 552-564,

Kucukmehmetoglu, M., Geymen, A., 2016 Optimization models for urban land readjustment practices in Turkey. Habitat International, 53, 517-533.

Leksono, B-E., Susılowat1, Y., Windayana, S., Yunındra, I. , 2011. Managing Land Registration Spatio Temporal Aspects in National Land Information System. FIG Working Week 2011, Bridging the Gap between Cultures, Marrakech, Morocco, 1822 May.

Lemmen, C.H.J., Van Oosterom, P.J.M., Eisenhut, C., Uitermark, H., 2010. The Modelling of Rights, Restrictions and Responsibilities (RRR) in the Land Administration Domain Model (LADM). FIG Congress 2010 Facing the Challenges Building the Capacity, Sydney, Australia, 11-16 April.

Lemmen, C., 2012. A Domain Model for Land Administration. PhD thesis, Technische Universiteit Delft The Netherland.

Lemmen, C., van Oosterom, P., Bennet, R., 2015. The Land Administration Domain Model. Land Use Policy, 49, 535-545.

Liang, Q., 2008. User Demands and Access Model for Temporal Cadastre in China. Master Thesis. International Institute for Geo-Information Science and Earth Observation Enschede, The Netherlands. 
Ozcelik, A., E., Nisanci, R., 2015. Developing Conceptual Data Model for Management Basis of Teafarmlands as SubComponent of Specialty Agricultural Crops. Sigma J Eng \& Nat Sci 33 (4), 2015, 521-537

Paasch, J.M., van Oosterom, P., Lemmen, C., Paulsson, J., 2015. Further modelling of LADM's rights, restrictions and responsibilities (RRRs). Land Use Policy, 49, 680-689,

van Oosterom, P.J.M., Lemmen, C.H.J., 2001. Spatial Data Management on a Very Large Cadastral Database. Computers, Environment and Urban Systems, 25, 509-528.

van Oosterom, P., Lemmen, C., 2002. Impact Analysis of Recent Geo-ICT Developments on Cadastral Systems. XXII FIG Congres, Washington DC, USA.

van Oosterom, P., Lemmen, C., 2015. The Land Administration Domain Model (LADM): Motivation, standardisation, application and further development. Land Use Policy, 49, 527534.

Zhang, N., Tuladhar, A.M., 2006. Modelling Spatio -Temporal Aspects of Cadastral System in China. XXIII FIG Congress, Munich, Germany, October 8-13.

Zevenbergen, J., 2002. Systems of Land Registration. Aspects and Effects. Publications on Geodesy, Netherlands Geodetic Commission, Delft, The Netherlands. 